\title{
DRAWING AT VISUAL ARTS TEACHERS EDUCATION: REFLECTIONS FROM DESIGNARE
}

\section{DESENHO NA FORMAÇÃO DE PROFESSORES DE ARTES VISUAIS: REFLEXÕES DO DESIGNARE}

DOI: http://dx.doi.org/10.5965/1984317815022019007

Flávia Pedrosa Vasconcelos

Universidade Federal de Santa Maria

flapedrosa@gmail.com

\begin{abstract}
RESUMO
Este trabalho intenta apresentar algumas reflexões da minha pesquisa doutoral, intitulada Designare: pontes artístico/educativas na formação docente em Artes Visuais. Esta pesquisa buscou construir uma interpretação sobre o Desenho e seu ensino na formação de professores de Artes Visuais, questionando o "saber desenhar" e o "não saber desenhar" na visão dos docentes que lecionam nessa área no nível superior. No processo metodológico, baseou os caminhos investigativos em três metodologias de pesquisa da Investigação Educativa Baseada nas Artes Visuais (Viadel, 2005): a Narrativa, a Autoetnografia e a A/r/tografia e com pesquisa em literatura especializada, problematização e justificativa em narrativa de memória e realização de entrevistas com docentes que lecionam Desenho em cursos de Licenciatura na área de Artes Visuais na Universidade do Porto - UPORTO e na Universidade Federal do Vale do São Francisco - UNIVASF. Com enfoque na compreensão da influência dos discursos em desenho e de desenhos como narrativas visuais no ensino/aprendizado de práticas docentes em Artes Visuais, assim como repensando as questões históricas nos currículos, eu analisei problemas das práticas pedagógicas de professores universitários e suas repercussões na formação de docentes em Artes Visuais no Brasil e em Portugal.
\end{abstract}

Palavras-chave: Artes Visuais, formação de professores, Desenho.

\begin{abstract}
This work aims to present some reflections of my PHD research, with the title Designare: pontes artistico/educativas na formação docente em Artes Visuais. This research sought to build an interpretation about the Drawing and its teaching in the Visual Arts teachers education, questioning the "how to draw" and the "not knowing how to draw" in the view of the teachers who teach in this area at the university. At the methodological process, based the investigative ways in three research methodologies of Educational Research Based on Visual Arts (Viadel, 2005): Narrative, Autoetnography and A/r/tography and with research in specialized literature, problematization and justification in narrative memory and interviews making with professors who teach Drawing in graduation courses in the area of Visual Arts at the University of Porto UPORTO and at the Federal University of the Valley of São Francisco - UNIVASF. Focused on the understanding of the influence of drawing discourses and from drawings as visual narratives on teaching/learning of teachers practices in Visual Arts as rethinking historical issues in curricula, I analyzed issues of pedagogical practices of university professors and their repercussions on contemporary Visual Arts Teachers Education in Brazil and Portugal.
\end{abstract}

Keywords: Visual Arts, Teachers Education, Drawing. 


\section{INTRODUCTION}

While I was developing my $\mathrm{PhD}$ research in Art Education at University of Porto UPORTO, I was concerned with which methodologies could help me develop a critical view about writing texts and drawing images as they how could dialogue with each other, each one with its potentials. Through the experience of drawing images and writing texts, I found drawing as more than a representative image, but a visual narrative that could express some ideas writing text cannot.

This research made me rethink the different possibilities for research in Art Education based on the Visual Arts. Concerning about drawing and drawing teaching as the basis of Visual Arts teaching/learning processes, I related discourses that emphasize ways of teaching drawing and its historical narratives that are connected with contemporary educational legislation. Through an ongoing effort to interpret and expand a viewpoint from the territories where I work and live, in Brazil, to where I was pursuing the $\mathrm{PhD}$ research, in Portugal, I relate both places bridging the Visual Arts Teachers Education.

The title of my PhD Designare: pontes artístico/educativas na formação docente em Artes Visuais (Designare: artistic/educative bridges at Visual Arts Teachers Education) has the word designare as the subject because of its meaning. According to the dictionary of Baldinucci (1681), disegnare is an Italian verb and has to do with the act of drawing, describing, delineating, whereas designare is a verb that comes from Latin and has a broader meaning since it involves draw, represent and describe signs and characteristics, in the proposition of delineating, describing and symbolizing forms.

Based on this conception, I (re) meant the concept of designare as the symbolic meeting of the drawing with the need of concrete representation of the individual, acting in two biases: as a process of transforming the look and, as an artistic/educational practice that exposes the place of the drawing in the formation of superior level in Visual Arts, mainly regarding the formation of professors and teachers of the area. 
Because of that, I can infer that drawing and drawing teaching were chosen as the main subject of my research for three reasons. Firstly, I understand drawing as a way of thinking from the invisible to the visible, making representation concrete. Secondly, drawing teaching is a relevant step towards developing technical, creative, expressive and cognitive competences and skills at school. Thirdly, I recognize drawing as an indispensable knowledge that confronts multiple and contemporary crises (ecological, social, cultural and economical).

It was important for me to analyze the expressions: "knowing how to draw" and "not knowing how to draw". These are conceived in different methodologies of drawing teaching and I get curious about what these discourses emphasizes, because the concepts, strategies and methodological contexts could be observed at the historical narratives as intrinsically connected in Visual Arts Teachers Education in Brazil and Portugal.

Discourses and practices are interconnected in teacher's experiences of teaching/learning, even if they do not understand this process. Because of this, I can suspect that pedagogical scholarship in most teacher education programs is centered within a decontextualized and non-critical discourse, and from this discourse there is a possible deterioration, specially at drawing teaching.

The problem of decontextualized drawing teaching can begin at Visual Arts Teachers Education in the curriculum and across all disciplines by teacher's didactics, influences the contexts of artistic production and teaching strategies that the future Art teachers learn and reproduce.

\section{METHODOLOGICAL DISCUSSIONS}

Bearing in mind the process of Visual Arts Teachers didactic development and the necessity for relevant connection between research and teaching drawing, I understand that developing methodologies in research is always a challenge. This is 
especially the case in Visual Arts Teachers Education, as it is a recent field of academic study in comparison with other areas of knowledge.

I think of research methodologies as being part of an interwoven system that articulates and recognizes areas of knowledge which are related to the research problems. For this reason, I chose a qualitative approach in my doctoral research to highlight issues, interpreting drawing and drawing teaching from a philosophical perspective to the practical experiences of teaching in Visual Arts Teachers Education.

My qualitative methodology and data collection for my PhD thesis consisted of the analysis, production and reflection of visual and written texts (Knowles \& Cole, 2008). The visual narratives were drawings I made through the process of investigate and connect dots at theories and practices of teaching drawing.

From this methodology, I developed the problem and the research questions in a process that makes use of several tools in order to make a contribution to the debate in the areas of Drawing, Drawing education, Visual Arts and Visual Arts Teachers Education.

I chose to work with the visual and written texts and drawing as a visual narrative as methodological tools that are characteristically utilized from an expanded field of research methodologies in Art Education, specifically from studies in Autoethnography (ELLIS, 2004; CHANG, 2008) and A/r/tography (IRWIN, 2004).

A/r/tography was an expanded field from Arts Education developed and published by Canadian researcher Rita Irwin and can also be considered a qualitative methodology of an Arts Education Research based in Visual Arts. It refers to developing theories and practices through a dialogue of the experience of being artist, being researcher and being teacher, thus bridging multiple meaningful professional identities.

It is not only a dialectical perspective that combines theories and artistic practices, educational and investigative in-between (a concept-key of A/r/tography) spaces. From this perspective, processes of researching are seen in their complexity, as 
being established by perception, as the questions are developed through specific experiences and not only are theorized (Irwin \& Springway, 2008).

Bridging the building of researching and being during the investigation, the Autoethnographic Narrative integrates the Autobiography with Ethnography (REEDDANAHAY, 1997; SPRY, 2001) by selecting and organizing critical understandings of the data collected through documents and interviews. With this data, the autoethnographer produces a reflective analysis through narrative that takes into account their own experience and its intersection with the context investigated.

I consider the use of Autoethnographic Narrative relevant in my research for two reasons: a) I could reflect on the tensions and issues related to the artistic and educational experiences developed; b) I developed a trajectory of thinking, analyzing and reflecting between concepts, geographical territories and historical narratives. By doing this, I also produced cultural and contextualized reflection.

A/r/tography and Autoethnography were integrated Arts Education Research based in Visual Arts that gave me a researching support to understanding the contexts of drawing, the tensions in-between from artist and teacher experiences and the artistic/educational practices in Visual Arts Teachers Education, through a reflection on the professional identity construction.

I based the written text as a narrative in Art Education on studies by Bruner (1991) and Galvão (1998). The narrative in Art Education is used in the text as a way of identifying contexts (BAUER AND JOVCHELOVITCH, 2002), being articulated with the Philosophy and History of Visual Arts Education, recognizing that practices exist within specific time and experiential contexts (McEWAN \& EGAN, 1998, p. 236) and recognizing my experiences during the process of researching as an $a / r /$ tographer and autoetnographer.

While rethinking the relevance of understanding theories and practices in Art Education, I agree with Pardiñas (2005, p. 138) that written narratives in Art Education are a dialectical resource with the visual narratives because their contribution are not 
only a valuable tool for understanding the experiences in the formation of the Visual Arts Teacher, they also act as a space where artistic and educational practices are made possible and rethought.

Thus, I proposed a methodology that combines narratives methods in Art Education with images as visual narratives on two levels that interact with each other: firstly, an Autoethnographic Narrative analyzes memories of teaching/learning drawing and secondly an $\mathrm{A} / \mathrm{r} /$ tographic narrative uses drawings and interpretations and allowed me to follow paths and create theoretical/practical bridges.

These approaches for investigative methodologies are part of what Viadel (2005, p. 260) called Educational Research Based on Visual Arts or Artelnvestigação Educativa, which I interpret as Art Education Research Based in Visual Arts. This methodological position connects educational research and artistic creation, based within a conversation between theories and practices and written narratives with visual narratives.

Also I can infer that the need for understanding the formation of the Visual Arts Teacher translates the notion of professorality in Pereira (2013) as the ability to understand the "continuous becoming" through experiences with everyday classes with the similar notion of "becoming" in Irwin and Springway (2008). I seize the latter notion focusing on the role of the teacher/artist/researcher or professor/artist/researcher within artistic and educational practices and their possibilities for dialogue in teaching drawing at the Visual Arts Teachers Education.

The $A / r$ /tographic Narrative methods are used in my research through the collection of images and the production of drawings, bringing additional reflections on the thinking, doing and teaching within drawing processes.

During the process of doing researching, I searched to delineate a trajectory to revisit the concepts, issues, and experiences. Thus, in addition to the usual experience of studying specialized literature, I made a conceptual and historical review on drawing 
education, an empirical study that enabled specific reflections on the contexts investigated.

\title{
3 ABOUT VISUAL AND WRITTEN NARRATIVES
}

\begin{abstract}
“Dis-seño: 'Dis' (distinto, aparte, separado), 'signo' (representación, señal, trazo). Realizar señales o trazos representativos de las cosas, pero separadas de ellas. Cuando se habla del diseño se entiende tanto la acción de diseñar como sus resultados." (HERNÁNDEZ, 1989: 14).

“[...] el <<Dibujo>> es siempre una acción ontológica que se establece como problema de sí mismo. En este sentido, tanto la vida como el quehacer del dibujo se establecen en lo que hay de hacer, en la necesidad de su propia definición, aquello que problematiza es lo que establece el sentido de su acción, redefiniendo en ello la propia condición de aquello que entendemos como dibujo." $\quad$ (MOLINA, 2002: 25).
\end{abstract}

The thesis Designare was produced as result of an investigation process that provided continuous dialogue between texts, contexts and interpretations of investigative experiences, since "[...] enseñar es conversar, aprender es conversar, experimentar es conversar.", (WAGENSBERG, 2008, p.102), understanding the imbricate connection between the context experienced thus exposing a formal conversation in narratives, knowing that these can also be understood through images as visual narratives.

Hernández (1989) states and Molina (2002), understanding that image and texts (visual and written narratives) complement each other. Hernández (1989) states that the etymology of the word drawing is connected to the concept that the drawing exists at the same time in its representational action and in its results as a production of mind.

Molina (2002) emphasizes the need to define the drawing, conceptualizing the processes of thinking and creating that establishes a meaning in the action of doing through representation. In this thesis, I agree with concepts by Hernández and Molina, and I understand that they complement each other. 


\section{EDUCAÇÃO, ARTES E INCLUSÃO}

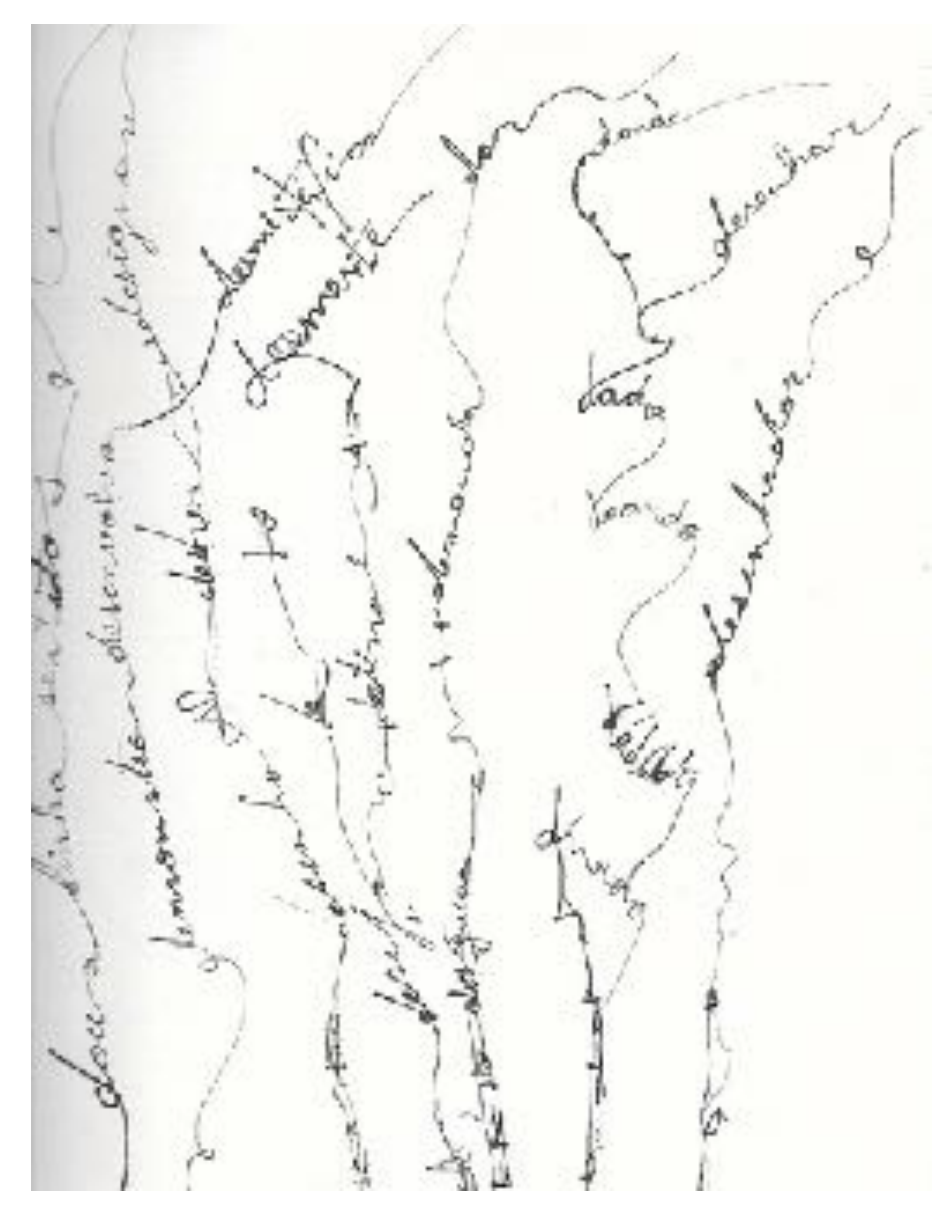

Figure 1. Drawing words about drawing feelings. 2013. Porto, Portugal.

Both researchers claim that drawing is a representation of experience and a narrative discourse that comes with the action of experiencing. In this case it is only possible for researching drawing if a researcher experience drawing.

As indicated by Hall (2003, p.15), the representation connects meaning and language. In drawing, this notion shows the acquired codes and graphic vocabulary in constant construction from the first years of any individual's life.

The drawing is not limited to a language based on communication issues or a unique language, but it makes use of language instruments in order to go beyond the communication of vision. It belongs to a complex system of representation that begins 


\section{EDUCACÃO, \\ ARTES E INCLUSÃO}

in the graphic vocabulary composition and allows its visualization through concrete or virtual surfaces.

Regarding the relation between words and pictures, I agree with Didi-Huberman's (2012) view that both are not opposite parts of language, because together they form a relevant connection in memory, like an archeological treasure or tomb. Drawing is a significative part of humanity's memories.

Even though the memory is a space of transience, the need for registration is expressed in a sense of urgency because each memory is always threatened by oblivion, each treasure threatened by looting, each tomb by grave desecration (DIDIHUBERMAN, 2012, p. 209).

Words and images each articulate a record where it is possible that what one told in one language is not the same thing as the other. As described by Barros (1998, p. $55)$, the images are words that we lack, and in the absence of words, the image covers this abyss. 


\section{EDUCAÇÃO, ARTES E INCLUSÃO}

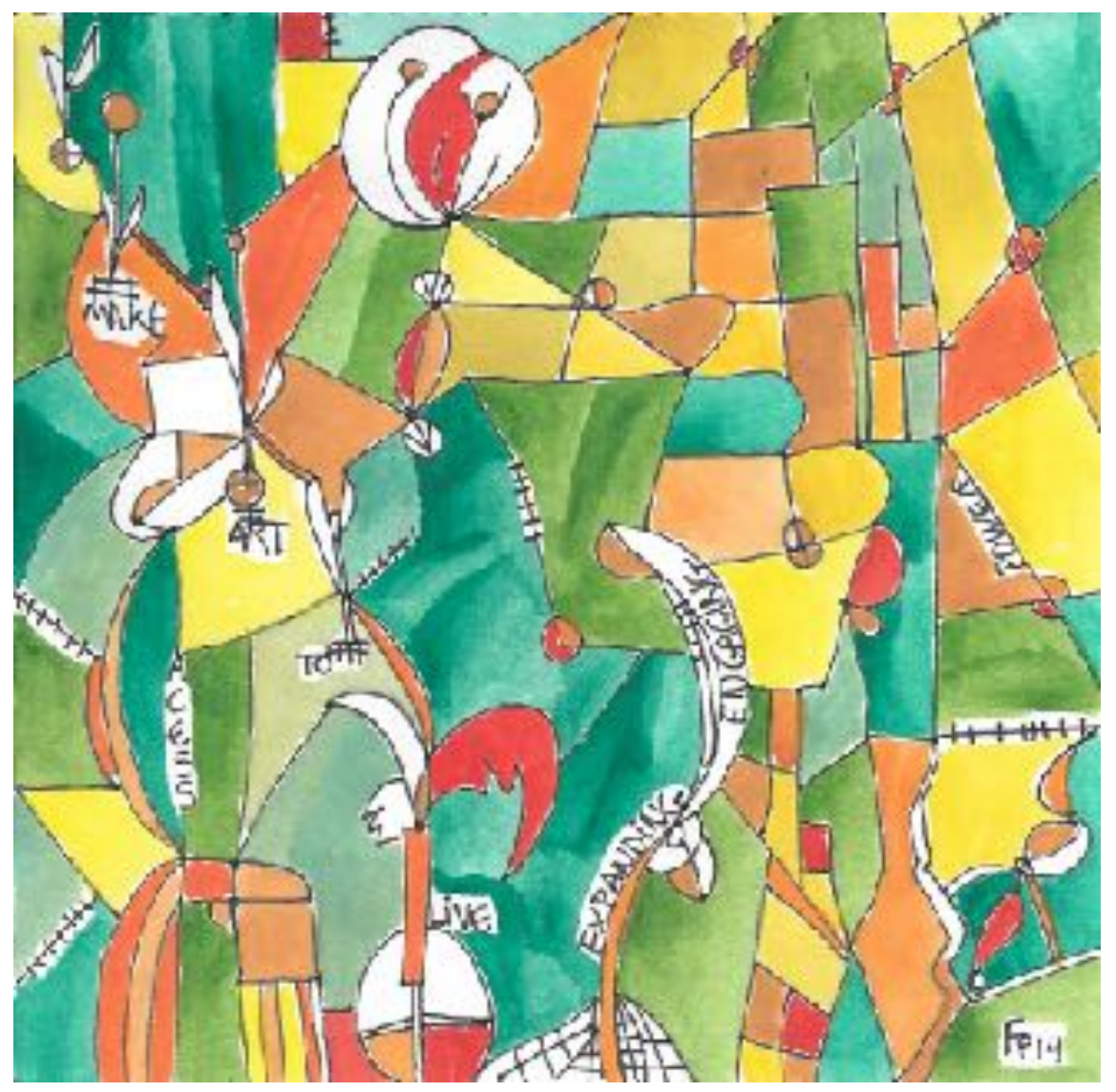

Figure 2. This came from a line in the middle. 2014. Porto, Portugal.

Understanding the space between words and images I chose some drawings produced during investigation process, rethinking that what an image can represent is not always the same as the word indicates. The production of meanings comes from different contexts and intersections and this go beyond in-between theories and practices of Arts Education Research Based in Visual Arts.

Regarding the poetics of the creative gesture, writing and images are generated through creative processes within the tension between limits and freedom and the tensions that they cause (SALLES, 1998). In this research, the drawing was the context 


\section{EDUCAÇÃO, \\ ARTES E INCLUSÃO}

through which a creative process was developed.

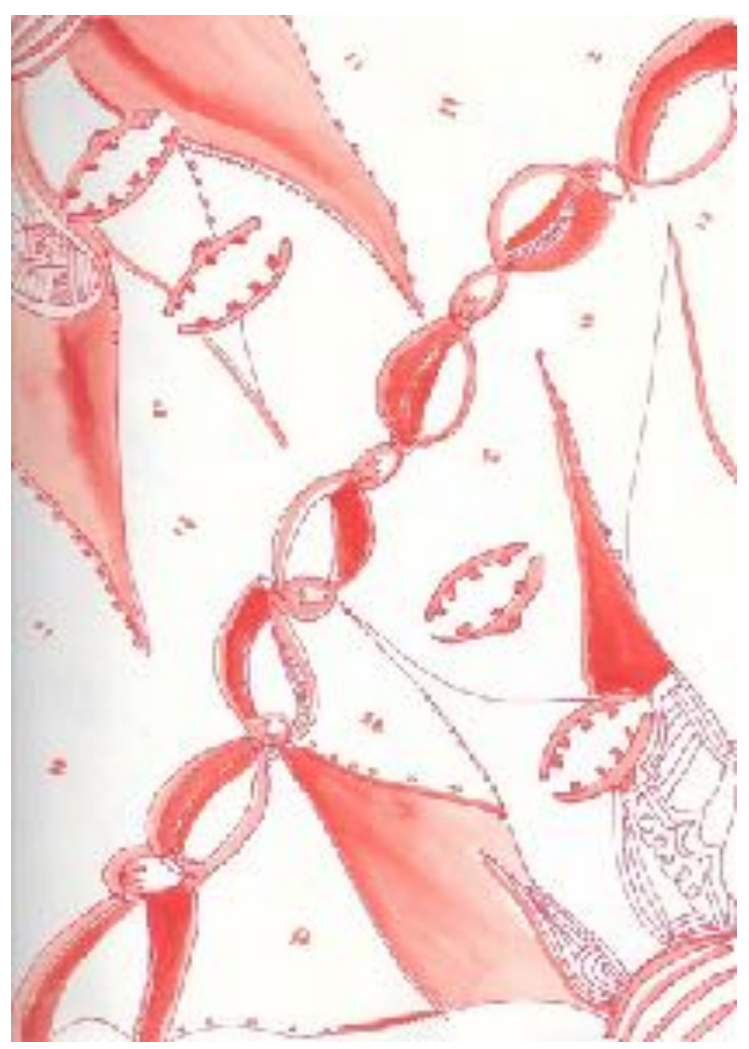

Figure 3. At the Fine Arts Faculty garden. 2014. UPORTO. Porto, Portugal.

Through the act of drawing I intended to understand and interpret the representations more accurately from the thinking processes, through to practical experiences in the field of research, in order to build inter-subjective artistic/educational bridges, as these drawing are realized from memory to line on a paper.

I drew at the research and searched to unite the act of drawing while I was detained in the research questions about discourses and practices of drawing education at Visual Arts Teacher Education in Brazil and Portugal, specifically at University of Porto - UPORTO (Portugal) and Federal University of San Francisco Valley - UNIVASF (Brazil). 


\section{EDUCAÇÃO, \\ ARTE'S E INCLUSÃO}

Within Art Education, the artistic and educational practices are visible from planning to thinking and producing arts. This means that the artistic and educational practices move from plan to construction of knowing, turning the contents into knowledge reinterpreted through creative processes in which the teacher interacts with students in their cultural, social and historical contexts.

This process required continual restructuring and reflecting on the conversations with the Visual Arts teachers as they discussed the drawing education. I observed the particular use of emphasis that advocate ways of thinking and of producing the drawing: a) from technique to technicality; b) from expression to free expressionism; c) from the creative process to creativity; d) from thought to cognition.

These discourses emphasized are made apparent when the History of Art Education is examined in the development of drawing education in each country investigated (Brazil and Portugal). They point out the difficulties of applying drawing related not only to educational policies but also with the context of dialogue between teacher and students at everyday classes.

As far as representation is concerned in drawing and the research experiences, I realized the complexity of understanding a concept that not only refers to an artistic practice but is also related to a product of a discourse. Therefore, I consider the drawing an artistic and educational practice, essential to human beings. 


\section{EDUCAÇÃO, ARTES E INCLUSÃO}

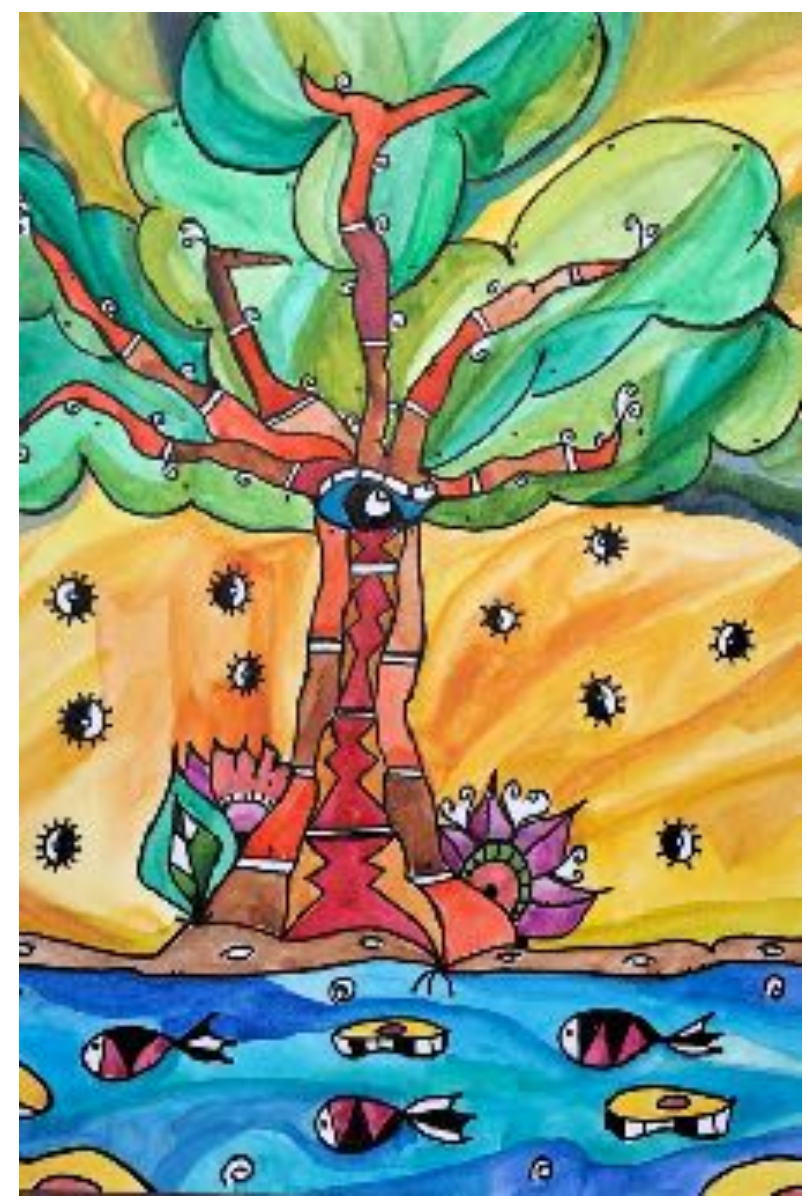

Figure 4. Ilustration at Extramuros scientific magazine. 2015. Porto, Portugal.

I can infer that the drawing education at Visual Arts Teachers Education in Brazil and Portugal has some gaps in the teaching/learning processes. It is the university professor's responsibility to give access to all the discourses, and all the possibilities of drawing.

In this sense it is necessary to move away from the imprisonment of knowledge that simplifies artistic and educational practices in the university environment, especially drawing and its teaching. It is essential to observe the complexity of Art Education and knowledge as multifaceted and intertwined. 


\section{BRIDGING DRAWING AT VISUAL ARTS TEACHERS EDUCATION IN BRAZIL AND PORTUGAL}

I understand the results of this research as part of a process of questioning univocal views on theories and practices at the university, given the importance of the influence of university professors on the development of competences and skills at Visual Arts Teachers Education.

Inquiring bridges through gaps where tensions are exposed. Through exposing the tensions and difficulties of teaching and learning drawing, I found the issues of "knowing to draw" interconnected with the use of formulas or recipes that are not contextualized. Many times, the use of a specific discourse emphasized by the drawing professor can expand the representational system deterioration causing an excess of technicality, expressivity or creativity.

Another point of deterioration in Visual Arts Teachers Education is apparent in the emphasis on gifts, talent and vocation. The gift does not exist, the talent is built by experience and the vocation is only discovered through developing talent. These are also areas of tension in drawing education.

The main areas of tension between the theory and practice of drawing and its teaching are articulated in different educational contexts: a) misguided educational policy; b) inconsistencies of the curriculum; and c) didactic choices made by teachers that only favor certain discourses. This leads to limits of pedagogical transposition and its contextualization in the processes of knowing.

Tensions in drawing education are rooted themselves and there is the danger of exaggerating if one is slow or acts in a hurry while working with artistic and educational theories and practices.

In the case of Brazil and Portugal, it is observed the Westernization of teaching/ learning drawing, as it has been enacted and reproduced massively in books and textbooks in the twentieth century and still observable in the XXI century.

It is at least obscene find today drawing teaching practices in schools based on a 
Western Education on Brazil and Portugal, assigning students to mere calculation of the look through the pursuit of an idealized and realistic virtuosity, and copying the preexisting models (PETHERBRIDGE, 2005; 2011).

It cannot be intended in Art Education the contemporary training in drawing at Visual Arts Teachers Education with only a classical vision or a modern vision with the use of an emphasis of discourse in injury to others. It is essential the diversity of possibilities, access to different theories, strategies and methodologies for an artistic and educational practice coherent that can promote critical understandings.

It is therefore imperative at Visual Arts Teachers Education, both in Portugal and in Brazil, teaching Drawing be perceived not only as a major focus in the curriculum, but also in the interpretation of his teaching and his learning have, simultaneously, a pragmatic function and a workup.

By fulfilling these two formative functions (CABAU, 2012, p.23) the drawing teacher inserts the need for systematization of perception and representation to education and develops cognitive teaching strategies, critical and creative in acquiring means to understand, review and realize what is being represented.

The act of knowing to draw goes beyond a narrow view and beyond the individual. It is a form of knowing how to work the graphic vocabulary and mental images collectively and collaboratively beyond representation in order to also via line review the context and the time in which we live. It seems to me that we must persist in the quest for balance in the experience of becoming a teacher, specifically within Visual Arts Teachers Education.

I conclude that the development of competences, skills and expertise in drawing education for Visual Arts Teachers must go through the fundamental recognition of tensions and varied discourses.

By recognizing the emphasis of discourse that teaching strategies and methodologies refer to, the teaching quality can be increased because it should be reflected contextually within the tensions in-between theories and practices of drawing. 
In this study, I have elaborated a particular view and highlighted the weight of history. I understand that there are no formulas to solve the problems in the teaching and learning of drawing. This only can be solved in the day by day classes and through dialogue between teachers and students, draw from the experiences of the process of teaching and learning.

Therefore, I propose that not only art teachers must have access to the knowledge produced through drawing. Drawing is indispensable not only to thinking in an Art Education Based Research in Visual Arts, but also as a significant representational bridge for all human beings.

\section{GOING BEYOND VISIBLE: DRAWING AT QUARANTINE}

Rethinking the space of drawing and its perception, this last part wishes to go beyond the research final considerations. As the distance of time which I written this article and time I revised it (2 years) and now in face of coronavirus quarantine in march 2020 at state of Rio Grande do Sul, Brazil and working from home, we can reflect about visual narratives from figure 1 to 4 with another possibilities.

The tangible things are rational, visible and concrete. They sometimes are configured as limited to creativity and innovation. To become the invisible seen is necessary to achieve the intangible, a place where the subconsciousness resides, and many things can appear making meanings.

In face of this, I understand the moment we live as a territory to expand and found some interesting ways of reading and experiencing through the drawings (Figure 1 to 4$)$ :

1) Figure 1 - writing words of feelings and how they are connected I lines or concrete forms, listening to a music and writing together the words come to you mind (they will make at the end also a singular drawing); 
2) Figure 2 - find three colors you like and try to imagine a place where you want to be now and where you are connected with it, make some dots and lines and utilize those colors;

3) Figure 3 - with just one color draw what you see or what you imagine. Try do not copy from another drawing you have made before;

4) Figure 4 - draw your connection with ecological issues, interpreting how human beings are not only related but a part of it.

There are many other possibilities, specially of you work with expanded drawing, with the body and different materials as textures, wood, paper. The suggestion is to be creative in times that intangible is blurred with so many bad feelings, news and open positive windows to new times are coming. They will be times that drawing must be potentialized, drawing is thinking, and thinking is being.

\section{REFERENCES}

BARROS, M. de. O guardador de águas. Rio de Janeiro: Record, 1998.

BAUER, M. \& JOVCHELOVIT, S. Entrevista Narrativa. In: BAUER, M.; GASKELL, G. Pesquisa qualitativa com texto, imagem e som. Petrópolis: Vozes. pgs. 90-113, 2002.

BALDINUCCI, F. Vocabulario Toscano dell Arte del Disegno. Accademici dela Crusca. Florença, Itália, 1681.

BRUNER, J. The Narrative Construction of Reality. Critical Inquiry, Chicago, v. 18 (1), 1991, pgs. 1-21.

CABAU, P. O dispositivo do desenho: A implementação da prática do desenho no ensino artístico contemporâneo. Leiria: Edições ESAD, 2012.

CHANG, H. Autoethnography as Method. Walnut Creek, CA: Left Coast Press, 2008.

DIDI-HUBERMAN, G. Quando as imagens tocam o real. Pós. Revista do

Programa de Pós-Graduação em Artes da Escola de Belas Artes da UFMG. v.2., $n^{\circ} 4$. Belo Horizonte: UFMG, 2012, pgs.204-219.

ELLIS. C. The Etnographic I: The autoethography. New York: Altamira Press, 2004. 
GALVÃO, C. Professor: o início da prática profissional. Tese de Doutorado em Educação. Departamento de Educação. Faculdade de Ciências. Universidade de Lisboa. Lisboa, Portugal, 1998.

HALL, S. The work of representation. In Hall, S. (Ed.). Representation: cultural representations and signifying practices. London: Sage, 2003, pgs. 13-64.

HERNÁNDEZ, P. Reseñas sobre el diseño de la enseñanza. In: HERNÁNDEZ, P. (org.). Diseñar y enseñar: teoría y técnicas de la programación y del proyecto docente. Madrid: Narcea,1989, pgs. 5-21.

IRWIN, R L. A/r/tography: a metonymic métissage. In Irwin, R. L.; Cosson, A. de. (eds.). A/rl tography: rendering self through arts-based living inquiry. Vancouver, Canada: Pacific Educational Press. p. 27-38, 2004.

\& SPRINGWAY, S. A/r/tography as practice-based research. In: CAHNMANN-TAYLOR, M.; SIEGESMUND, R. (Eds). Arts-Based Research in Education. Foundations for Practice. New York: Routledge. 2008, pgs. 103-124.

KNOWLES, J. G. \& COLE, A. L. Handbook of the Arts in Qualitative Research: perspectives, methodologies, examples and issues. Los Angeles: Sage Publications, 2008.

McEWAN, H. \& EGAN, K. (comps.). La narrativa en la enseñanza, el aprendizaje y la investigación. Buenos Aires: Amorrortu, 1998.

MOLINA, J. J. G. Máquinas de dibujar: territórios y escenarios del dibujo. In: MOLINA, J. J. G. (coord.). Máquinas y herramientas de dibujo. Madrid: Cátedra, 2002, pgs. 15-81.

PARDIÑAS, M. J. A. El vuelo de la mariposa: la investigación artístico-narrativa como herramienta de formación. In: VIADEL, R. M. (ed.). Investigación en Educación Artística: temas, métodos y técnicas de indagación sobre el aprendizaje de las artes y culturas visuales. Granada: Editorial Universidad de Granada, 2005.

PEREIRA, M. V. Estética da professoralidade: um estudo crítico sobre a formação do professor. Santa Maria, RS: Editora da UFSM, 2013.

PETHERBRIDGE, D. On models and Mickey Mouse. International Journal of Art and design Education. 24 (2), 2005. pgs.126-135.

.The primacy of drawing. Histories and theories of practice. New Haven and London: Yale University Press, 2011.

REED-DANAHAY, D. (Ed.). Auto/Ethnography: rewriting the self and the social. Oxford: Berg, 1997.

SALLES, C. A. Gesto inacabado: processo de criação artística. São Paulo: FAPESP, Annablume, 1998.

SPRY, T. Performing autoethonography: an embodied methodological praxis. Qualitative Inquiry, 7, 2001.pgs. 706-732 


\section{EDUCACÃO, ARTES E INCLUSÃO}

VIADEL, R. M. 'La Investigación Educativa Basada en las Artes Visuales' o 'Artelnvestigación Educativa'. In VIADEL, R. M. (ed.). Investigación en Educación Artística: temas, métodos y técnicas de indagación sobre el aprendizaje de las artes y culturas visuales. Granada: Editorial Universidad de Granada, 2005, pgs.223-274.

WAGENSBERG, J. Si la naturaleza es la respuesta i cuál era la pregunta : y otros quinientos pensamientos sobre la incertidumbre. Tusquets: Barcelona, 2008.

Recebido em 09 de Março de 2018 Aprovado em 19 de Março de 2020 